Americký podíl na reorganizaci české ošetřovatelské školy v Praze v letech 1920-1923

\title{
United States share in the reorganization of the Czech nursing school in Prague in 1920-1923
}

\section{Růžena Zaoralová, Jana Kutnohorská, Zdeňka Mikšová}

\author{
Ústav ošetřovatelství, Fakulta zdravotnických věd, Univerzita Palackého, Olomouc, Česká republika
}

\begin{abstract}
ABSTRAKT
Východiska: Výzkum byl motivován snahou prohloubit současné poznání o názory amerických expertů, kteří na základě svých zkušeností věnovali reorganizaci ošetřovatelské péče v meziválečném Československu větší pozornost než oficiální československé orgány.

Cíl: Objasnit úlohu ošetřovatelek Amerického Červeného kříže a expertů Rockefellerovy nadace při implementaci moderních přístupů v ošetřovatelství na české ošetřovatelské škole v Praze v letech 1920-1923.

Metody: Práce je založena na retrospektivní analýze periodik a dokumentů Amerického Červeného křriže a Rockefellerovy nadace jako dvou hlavních amerických organizací podílejících se na reorganizaci ošetřovatelské péče v meziválečném Československu. Kromě toho byly využity detailní informace z dobové publikace History of American Red Cross Nursing (New York, 1922), české archivní fondy (Spolek diplomovaných sester, Korespondence Alice Masarykové) a situační zpráva Frances Crowellové o stavu ošetřovatelské péče v Československu z roku 1922. Výstupy: Zaměření na krátký časový úsek let 1920-1923 umožnilo postihnout ve větším detailu a v širších souvislostech obtíže, s nimiž se americké ošetřovatelky při zavádění moderních metod v Československu musely potýkat. Výzkum přispěl k dosavadnímu poznání problematiky ve třech oblastech: 1 . Z dat o profesní dráze amerických ošetřovatelek se podařilo doložit, že do Československa přicházely sestry vyškolené v USA, které získaly praktické a organizační zkušenosti v ošetřovatelské službě za první světové války. 2 . Hlavním problémem ve výuce byla nutnost změny poměru teorie a praxe ve prospěch praktických předmětů a zvýšení prestiže oboru. Do osnov byly včleněny nové kurzy o výživě invalidů, $\mathrm{z}$ bakteriologie, etiky a dějin ošetřovatelství; zcela nově byla prosazována výuka zdravotní a domácí péče o děti vedená odbornou školitelkou. 3. Doporučení amerických ošetřovatelek pro další zkvalitnění výuky a ošetřovatelské péče zahrnovala zř́zení speciálního ošetřovatelského odboru při ministerstvu zdravotnictví, který měl legislativně upravit kompetence a postavení sester včetně požadavků na jejich vzdělání, evidovat registrované sestry a provádět inspekci veřejných zdravotnických zařízení. Mezi návrhy se rovněž objevuje důraz na rozšíření sítě státních ošetřovatelských škol.

Závěry: Výzkum ukázal na šiři problémů, jež bylo třeba $v$ té době řešit. Působení zahraničních ošetřovatelek Amerického Červeného křiže a expertů Rockefellerovy nadace za dané situace je možno označit za svého druhu fenomenální počin, jehož vliv nebyl dosud dostatečně doceněn. Mnohé tehdy řešené problémy (vymezení kompetencí, otázka ošetřovatelských standardů, edukace pacientů) jsou aktuální i dnes.
\end{abstract}

\section{ABSTRACT}

Background: The research was motivated by the efforts to deepen the present knowledge in the opinions of American experts, who, on the basis of their experience, paid more attention to the reorganization of nursing care than official bodies in inter-war Czechoslovakia.

Aim: To clarify the role of Red Cross of America nurses and Rockefeller Foundation experts in the introduction of modern approaches in nursing at Czech nursing school in Prague in the years of 1920-1923.

Methods: The study is based on the retrospective analysis of historical documents and periodicals originated from the activities of Red Cross of America and Rockefeller Foundation as two main American organizations being involved in the reorganization of nursing care in inter-war Czechoslovakia, including the American Journal of Nursing from the years of 1920-1923 and the voluminous History of the American Red Cross Nursing (New York, 1922). Ascertained data were compared with those from the Czech archival funds (Spolek diplomovaných sester - Association of Graduate Nurses, Correspondence of Alice Masaryková) and with a detailed situation report on nursing conditions in Czechoslovakia by Frances Crowell from 1922. 
Outputs: The focus on the short period of 1920-1923 made possible to cover in more detail and in the broader context all difficulties which the American nurses were faced with. The research contributed to the present state of knowledge in three fields: 1. Data on the professional career of American nurses coming to Czechoslovakia evidence that they were trained experts who gained practical and organizational experience in nursing service during the World War I. 2. The main problem in teaching was the need for relation change between theory and practice in favour of practical subjects and for increase in the prestige of nurses. New courses on nutrition for people with disabilities, on bacteriology, ethics and history of nursing were incorporated into the curriculum. Managing children's home healthcare was another completely new element in teaching. 3 . The recommendation of American nurses for the next improvement of education and nursing care included the proposal to establish a special nursing division at the Ministry of Health which ought to provide for nurses' authority and status, including requirement for their education, to keep files of registered nurses and to provide public health facilities inspections. Emphasis was also placed on expanding the network of state nursing schools.

Conclusions: The research proved a range of problems which had to be solved at that time. The activities of American Red Cross nurses and Rockefeller Foundation experts in adverse conditions can be described as phenomenal feat whose influence has not yet been fully appreciated. Many problems solved at that time, like competence specifications, nursing standards or patient education, are topical even today.

\section{KLÍČOVÁ SLOVA}

ošetřovatelské školství, pražská ošetř̌ovatelská škola, organizace studia, Americký Červený křriž, Rockefellerova nadace

\section{KEY WORDS}

Nursing education, Prague nursing school, the organization of study, American Red Cross, Rockefeller Foundation

\section{ÚVOD}

Současné kvalitativní změny $\mathrm{v}$ ošetřovatelství, mezi jinými ustavení regulovaných profesí, zavádění jednotné vědecké terminologie či uplatňování praxe založené na důkazech, jsou výsledkem široké mezinárodní spolupráce, jejíz počátky sahají do období po první světové válce, kdy Americký Červený křiž a Rockefellerova nadace $\mathrm{v}$ rámci celosvětové pomoci začaly ve zdravotnictví prosazovat anglosaský ošetřovatelský model. Měnící se podmínky $\mathrm{v}$ současném profesním vzdělávání nelékařských zdravotnických pracovníků a vymezování nových kompetencí v rámci jednotné evropské legislativy pro výkon povolání sestry vybízejí ke zkoumání odlišných prístupů a podmínek v minulosti a $\mathrm{k}$ hledání inspirací a paralel. Práce se pokouší odpovědět na tři výzkumné otázky: 1 . jaké byly profesní zkušenosti amerických ošetřovatelek vyslaných na misi do Československa v roce 1920, 2. jak se pod jejich vlivem změnila organizace a náplň výuky na české ošetřovatelské škole v Praze a 3. jaká byla doporučení amerických sester pro další zkvalitnění výuky a ošetřovatelské péče po jejich odchodu $\mathrm{z}$ Československa v roce 1923. Těmto problémům nebyla dosud $\mathrm{z}$ české strany věnována patřičná pozornost. Práce vychází z detailních informací o iniciativách Amerického Červeného křiže (American Red Cross, ARC) $\mathrm{v}$ meziválečném Československu publikovaných jak v obsáhlé dobové príručce History of American Red Cross
Nursing (New York, 1922), tak na stránkách The American Journal of Nursing. Ke komparaci byly využity také méně podrobné prameny české provenience: periodikum Zprávy Československého červeného křžže a archivní fondy Spolek diplomovaných sester a Korespondence Alice Masarykové. Klíčový význam z pohledu Rockefellerovy nadace na stav ošetřovatelství v poválečném Československu mají zprávy, hodnocení a doporučení Frances Elisabeth Crowellové, jež ve své diplomové práci shrnula Elizabeth Vickersová.

\section{POPIS REŠERŠNÍ STRATEGIE}

Kritériem výběru pramenů a literatury bylo působení amerických ošetřovatelek na pražské ošetřovatelské škole v letech 1920-1923. Informace byly získány z databází PROQUEST, EBSCO, JSTOR, GOOGLE Scholar, BMC, OVID, PubMed, Kramerius, Badatelna.eu, My Heritage, Ingenta Connect. Jejich prostřednictvím bylo nalezeno celkem 45 titulů, $\mathrm{z}$ nichž 24 bylo vyřazeno, nebot' se neshodovaly se stanovenými cíli. Použito bylo celkem 13 článků, čtyři monografie, jedna diplomová práce a dva archivní fondy z Archivu hlavního města Prahy a Masarykova ústavu - Archivu AV ČR. Nevyužity zůstaly obtížně dostupné archivní fondy uložené v USA. Získaná data byla rozčleněna do těchto tři tematických kategorií: 1. reprezentanti amerických institucí, 2 . formy zahraniční pomoci, 3. organizace studia. 


\section{První světová válka a vznik dvouleté ošetřovatelské školy}

Počátky ošetřovatelského oboru v nově vzniklé republice byly velmi skromné. V roce 1918 bylo vyškoleno jen deset diplomovaných sester z řad prvních absolventek státní dvouleté ošetřovatelské školy při Všeobecné nemocnici v Praze. I když škola, od počátku rozdělená na českou a německou sekci, byla založena již v roce 1914, výuka na ní byla pro nedostatek učitelů zahájena teprve v květnu 1916, přičemž na každou z obou sekcí bylo přijato pouze 15 žákyň. Teoretický výcvik na české škole vedené Františkou Fajfrovou zajištovaly absolventky vídeňské ošetřovatelské školy Olga Holubková, Gizela Bártová a Božena Březinová (1). V Praze tehdy převažovala podle vídeňského vzoru výuka lékařských disciplín nad praktickými ošetřovatelskými předměty, jejichž studium vycházelo z prríručky Florence Nightingalové Kniha o ošetřování nemocných, vydané v českém překladu v roce 1874.

První světová válka eskalovala mnoho zdravotních a sociálních problémů, $\mathrm{k}$ jejichž řešení podstatnou měrou přispěl Červený kříž. Všeobecný vzrůst prestiže této organizace na mezinárodním poli vedl 6. února 1919 k ustavení samostatné složky také v Československu. Potřeba kvalifikovaných ošetřovatelských sil byla $\mathrm{v}$ té době velmi naléhavá, a tak před ošetřovatelským školstvím stála výzva navýšit počet kvalifikovaného zdravotního personálu a zkvalitnit jeho odborný výcvik. Toho si byla dobře vědoma Alice Masaryková, která ve funkci první předsedkyně Československého červeného kříže (ČSČK) zahájila ještě téhož roku v Pařiži jednání s představiteli ARC a Rockefellerovy nadace (Rockefeller Foundation, RF) o budoucí pomoci a spolupráci.

\section{Pařižská jednání se zástupci Amerického Červeného kříže}

ARC vyslal v letech 1918-1922 asi 600 vyškolených ošetřovatelek a jejich asistentek na práci do poválečné kontinentální Evropy, Ruska a na Blízký Východ. Nejvíc se jich uplatnilo v Polsku, Československu, na Balkáně a na Sibiř̀i. Smysl těchto misí spočíval nejen ve zlepšení ošetřovatelské péče v globálním měřítku, ale i v posilování vlivu USA ve světě na mimopolitické úrovni (2). Podporu odborných ošetřovatelských škol si ARC vytkl jako svou prioritu. Díky iniciativě Alice Masarykové a jejího otce se pražská škola stala první destinací ARC ve střední Evropě, o něco později byly s podporou ARC založeny také školy v Poznani a ve Varšavě (3).

$\mathrm{Na}$ zmíněném jednání v Paříži v roce 1919 bylo dohodnuto, že česká část pražské ošetřovatelské školy přejde v roce 1920 do správy ČSČK, zatímco německá sekce zůstane $\mathrm{v}$ rukou státu, což jí dávalo záruku lepšího finančního zajištění. Výuka v německých třídách probíhala $\mathrm{v}$ tradičním stylu vídeňské ošetřovatelské školy, kdežto předností české sekce pod správou ČSČK byla mnohem větší provázanost se Spojenými státy, která umožnila implementovat do českého ošetřovatelství moderní prístupy vyzkoušené a osvědčené $\mathrm{v}$ anglosaských zemích. Vedením a reorganizací české školy byla na trri roky pověřena Marion Geneth Parsonsová, diplomovaná sestra městské nemocnice $\mathrm{v}$ Bostonu, která se $\mathrm{v}$ té době vrátila $\mathrm{z}$ vojenské služby jako vrchní sestra Všeobecné nemocnice Britského expedičního sboru. Její mise v Praze byla na žádost československé vlády financována $\mathrm{z}$ prostředků ARC. $\mathrm{Na}$ místo asistentky budoucí ředitelky byla vybrána Alotta M. Lentellová, diplomovaná sestra, bývalá zástupkyně ředitelky ošetřovatelské školy při nemocnici v Newton Lower Falls ve státě Massachusetts, která v roce 1915 sloužila u Červeného křriže v La Panne v Belgii a v letech 1918-1919 u Námořní zdravotní služby (4). $\mathrm{K}$ těmto dvěma zkušeným ošetřovatelkám se následně prripojily další tři americké spolupracovnice: Blanche Kacenová, Pansy Besomová a Rachel Torranceová.

Očekávání z americké strany byla veliká. Alice Fitzgeraldová, vrchní sestra Evropského výboru ARC, absolventka prestižní ošetřovatelské školy na Univerzitě Johnse Hopkinse, se o tomto projektu vyjadřovala velmi optimisticky: „Mám pocit, že Československo prochází obdobím přizpusobování, a zdá se, že panuje velmi vstřícná nálada vůči zmènám. To je celkem patrné ze skutečnosti, že sestry Červeného křiže vyučuji nyní v Praze domácí péći a hygienu nemocných šedesát žen, které jsou studentkami třetího ročníku mediciny. Jak zdůrazñuje Alice Masaryková, která tento projekt podporuje, tyto budoucí lékařky budou mít určitě větši pochopení pro profesi zdravotnich sester, než jaká byla kdy dřive, a na základě osobní zkušenosti si uvědomí, že ošetrovatelství by nadále nemělo být považováno za ponižující zamèstnáni" (4).

\section{Finanční pomoc ostatních amerických organizací}

Rovněž ze strany RF dostalo Československo, považované za zemi s ideálními podmínkami, finanční podporu jako první ve střední Evropě. Zůstává otázkou, nakolik československý projekt předjímal jednotný model zdravotního programu, který měl být aplikován $\mathrm{v}$ celém regionu (5). $\mathrm{Na}$ ošetřovatelskou školu v Praze rovněž přispěly Mezinárodní výbor Červeného křiže v Ženevě, Liga Červených křížů, Nadace Herberta Hoovera, Křestanské sdružení mladých mužů (YMCA) a žen (YWCA) a také fond Charlese Cranea, zámožného amerického podnikatele, slavjanofila a sobního přítele Tomáše G. Masaryka, z jehož prostředků se hradila stavba školní budovy (6). 


\section{Studijní pobyty v USA}

Na schůzce v Pařižiz se ARC zavázal, že bude ročně hradit dva studijní pobyty československých ošetřovatelek ve Spojených státech. RF byla ještě štědřejší, nebot jen během prvních tří let vycestovalo na její náklady celkem 22 českých studentek. Jako první byly v roce 1920 vyslány Božena Březinová a Františka Růžičková, které zamírily na Massachusettskou ošetřovatelskou školu při Všeobecné nemocnici $\mathrm{v}$ Bostonu. Protože však musely nejdřív projít jazykovou průpravou, mohly na školu nastoupit až 1. ledna 1921. U některých českých ošetřovatelek se navíc objevily zdravotní problémy, které původní plány zhatily. Božena Březinová se krátce po nástupu do školy nervově zhroutila, byla poslána na vyšetření v MacLeanově nemocnici, kde zůstala až do podzimu 1921, a poté se vrátila do Československa. Místo ní přijela do USA Vilma Černá, čerstvá absolventka pražské ošetřovatelské školy, zčásti již zaškolená Marion Parsonsovou. Nejprve působila $\mathrm{v}$ presbyteriánské nemocnici v New Yorku, aby se blíže seznámila s americkými metodami v ošetřovatelství, a poté nastoupila na Kolumbijskou univerzitu jako mimořádná studentka $\mathrm{v}$ oboru řízení ošetřovatelských škol. Kvůli nedostatečné znalosti angličtiny však její studium bylo málo efektivní, a tak byla v létě 1922 prreřazena do Massachusettské všeobecné nemocnice. V zárí téhož roku se vrátila do Prahy, aby působila jako asistentka Marion Parsonsové (7), avšak krátce po návratu domů zemřela (8).

\section{Změny v organizaci studia}

Učitelský sbor české ošetřovatelské školy, který zpočátku tvořila Marion Parsonsová s Alottou Lentellovou, záhy rozšiŕila Blanche Kacenová, česko-americká diplomovaná sestra, školená specialistka v oblasti ř́zení ošetřovatelských škol, která jako jediná $\mathrm{z}$ amerických ošetřovatelek uměla česky. Znalost češtiny jí umožňovala věnovat se supervizi nemocničních předpisů a vést odbornou praxi na nemocničních odděleních bez tlumočnice (9).

Do výuky se podle potřeb zapojovaly i další pracovnice ARC. Jednou z velmi zkušených byla Pansy Besomová, absolventka ošetřovatelské školy ve státě Delaware, která působila jak ve veřejné zdravotní službě v Stamfordu ve státě Connecticut, tak jako sestra dětské domácí péče v Bostonu. V Polsku a Československu pracovala na operačním sále a v dispenzáři a byla také instruktorkou ošetřovatelských kurzů. Ve funkci ředitelky ošetřovatelské služby ARC v ČSR dohližela na budování a správu dětských zdravotních center a podílela se na zavedení kompletní zdravotní a sociální evidence o každém dítěti v zemi. Besomová se zajímala zejména o to, jak sledovat dítě, když je zpět doma, nebot' $\mathrm{v}$ tomto směru neexistoval žádný plán (10). Její asistentkou byla May Louise Whiteová. Kromě nich instruktáž domácí péče prováděla ve spolupráci s ČSČK také Mary H. Bethelová (7). V letech 1920-1922 se do výuky zapojila rovněž Rachel Torranceová, asistentka Helen Scott Hayové, vrchní sestry Evropské divize ARC. Torranceová rok před tím pracovala jako vrchní sestra $v$ Bělehradě a v roce 1923 se stala ředitelkou ošetřovatelské školy v Sofii (7).

Ředitelka školy organizovala kromě dvouletého studia také čtyřměsíćní ošetřovatelské kurzy, které ovšem museli kvůli jazykovým problémům vyučovat převážně lékaři pražské univerzity. Reorganizace školy vyžadovala novou obsahovou náplň studia. Za nejnaléhavější se považovala potřeba změnit poměr teorie a praxe ve prospěch praktických předmětů. Parsonsová postupně včlenila do osnov kurz o vaření a výživě invalidů a kurz z bakteriologie, nově se začal klást důraz na etiku a dějiny ošetřovatelství (7). Nové osnovy školy připravila během svého pobytu v Československu v roce 1921 Mary McDowellová, významná americká sociální pracovnice, zakladatelka domu pro imigranty při univerzitě v Chicagu (Hull House) a blízká př́telkyně Alice Masarykové (11). Mezi pilíre zavedených změn patřila výuka angličtiny a přechod na anglickou literaturu namísto německé. Nově pojaté studium bylo zaměřeno tak, aby zdravotní sestra získala nejen široký rozhled a sociální cítění, ale také odborné znalosti a dovednosti. Součástí výuky byly anatomie, psychologie, bakteriologie, fyziologie, hygiena, interní, chirurgické a gynekologické ošetřovatelství, péče o kojence a děti, psychiatrie, nemocniční administrativa, občanská výchova a zákony o veřejném zdraví a sociální péči. Posledně jmenovaný předmět zahrnoval ošetřovatelskou praxi v terénu a vyžádal si přidělení dobře vyškolené sestry (9).

Významným počinem pro šíření znalostí o moderních prrístupech $\mathrm{v}$ ošetřovatelství bylo vydání učebnice Domácí zdravověda a ošetrování nemocných přední odbornice Jane Armindy Delanové, zakladatelky ošetřovatelské divize ARC a ředitelky ošetřovatelských škol v New Yorku a Filadelfii. Jednalo se o překlad druhé verze textu upraveného Anne Hervey Strongovou, profesorkou ošetřovatelství na Simmons College $\mathrm{v}$ Bostonu. Tato kniha, kterou v roce $1921 \mathrm{z}$ angličtiny přeložil Jaroslav Lenz, primář nemocnice sv. Alžběty v Praze, byla ve své době natolik moderní, že podle jejích propracovaných zásad byla základní péče poskytována ještě dlouho po druhé světové válce $(12,13)$.

Od počátku bylo zřejmé, že jedna škola nestačí a bude třeba zřizovat další (14). To se však dlouho $\mathrm{z}$ řady důvodů nedařilo. $\mathrm{O}$ to větší byla odpovědnost pražského ústavu, který ve své době jako jediný v Čes- 
koslovensku poskytoval nejen kvalifikovanou péči o nemocné, ale musel rovněž připravovat sestry na profesi budoucích učitelek, řídících pracovnic a vedoucích představitelek oboru.

Přes všechny problémy vnímaly americké ošetřovatelky svou misi v Československu jako úspěšnou. Zájem byl zejména o krátkodobé kurzy, jichž se pravidelně účastnilo asi 60 adeptek. Zhruba $\mathrm{z}$ poloviny se jednalo o mimopražské studentky, které byly ubytovány v budově školy. Snaha o proporční zastoupení motivovala vedení školy k přijímání dívek nejen z Prahy, ale i z Moravy a ze Slovenska (15). Posluchačky pocházely většinou $z$ nižší stř̌ední třídy a zpočátku se od všech vyžadoval měsíční poplatek ve výši 70 korun československých. Nebylo snadné získat pro studium také dívky $\mathrm{z}$ vyšších sociálních vrstev. Přetrvávající předsudky o ošetřovatelství jako profesi pro materiálně zajištěné dámy bez kvalifikace živil i př́stup mnoha lékařư, kteři raději přijímali sestry s co nejnižším vzděláním a $\mathrm{k}$ ošetřovatelské škole zaujímali vesměs neprátelský postoj (7).

Kuratorium školy se skládalo $\mathrm{z}$ devíti členů, mezi něž patřili zástupce zemské politické správy, ředitelka ČSČK, ministr veřejného zdravotnictví a tělesné výchovy, ředitel Všeobecné fakultní nemocnice, tři profesoři Lékařské fakulty Karlovy univerzity, předsedkyně Dámského klubu a ředitelka školy (1). Postupem času se Parsonsové podařilo vyškolit tento výbor tak, aby jeho členové měli vủbec povědomí o tom, jaké klást požadavky na kandidátky učitelské profese a kam školu směřovat. Chyběly zkušenosti s vedením výuky. Lékařům bylo třeba vysvětlovat, jaká je hodnota dobré ošetřovatelky. To se ovšem neobešlo bez konfliktů, nebot někteří členové kuratoria $\mathrm{z}$ řad vlády a univerzity a také širší lékařská veřejnost se zpočátku stavěli ke škole vedené Parsonsovou nepřátelsky. Ukázalo se, že hlavní problém spočívá v nepochopení české mentality ze strany americké ředitelky, která se pokládala za svého druhu spasitelku a pro postoje českých odborníků měla jen malé porozumění. Nasvědčuje tomu dopis Marion Parsonsové z května 1920 adresovaný Claře D. Noyesové, ředitelce ošetřovatelské divize ARC, v němž jeho autorka vyjadřuje přesvědčení, že Evropané potřebují americké ošetřovatelky víc než cokoli jiného (2). Našli se však i lékaři, kteř́ se dokázali nad tyto rozmíšky povznést, záměr Parsonsové pochopili a se školou úzce spolupracovali. K nim patřil na prvním místě internista profesor Ladislav Syllaba, který škole svěřil k výcviku dvě svá oddělení (7).

\section{Uznání ošetřovatelské profese}

Záměry ČSČK pozvednout úroveň ošetřovatelské profese zkvalitněním vzdělávání a přijetím osvědče- ných př́stupů a zkušeností erudovaných amerických ošetřovatelek byly ovlivňovány řadou faktorů. Patřil $\mathrm{k}$ nim nerovný vztah mezi lékařem a sestrou a z něho plynoucí postoje $\mathrm{k}$ ošetřovatelské profesi, podmínky výkonu ošetřovatelského povolání, angažovanost absolventek ošetřovatelské školy a $\mathrm{v}$ neposlední řadě i odlišné př́stupy $k$ ošetřovatelskému školství. Prosazení a uznání ošetřovatelské profese hodně záviselo na změně myšlení celé společnosti. Nejen v Evropě, ale i ve Spojených státech převažoval $\mathrm{v}$ první polovině 20 . století názor, že ošetřovatelství je omezeno jen na určitý okruh poznatků a že tudíž nemůže zasahovat do medicínských kompetencí. Naproti tomu medicína měla moc zasahovat do ošetřovatelství. Podle tehdy všeobecně akceptovaného mínění lékař potřebuje vzdělání, kdežto sestra trénink. Praktické výuce odpovídaly i zkoušky, které kladly větší důraz na racionální řešení praktických problémů na úkor analytických a konceptuálních schopností. Tento prístup upevňoval hierarchizaci ve vztazích lékař - sestra a byl príćinou rutinního pojetí ošetřovatelství. Mocenský vztah lékař - sestra byl ovlivněn řadou sociálních nástrojů, které vedly $\mathrm{k}$ omezení vzdělávání sester co do hloubky a šiřre možností. Vycházelo se z předpokladu, že ošetřovatelské poznání žen je založeno na empirii, zatímco mužské - lékařské poznání má svůj základ ve vědeckých teoriích (16).

Budovat respekt $\mathrm{k}$ ošetřovatelské profesi paradoxně znesnadňovala i sama Alice Masaryková, když svou autoritou posilovala vnímání ošetřovatelství jako nemocniční funkce, kterou mohou vykonávat řádové a méně vzdělané sestry, zatímco za doménu vzdělanějších žen považovala sociální práci, na jejíž podporu založila v Praze školu. Americká badatelka Elizabeth Vickersová soudí, že Masaryková tímto svým prístupem podpořila nerozhodnost ministerských úředníků, kteří problematice ošetřovatelství nerozuměli a zdráhali se proto provádět inovativní reformy (17, 18). Na změnu tohoto postoje se snažil svými aktivitami a osvětou působit ARC podporovaný Spolkem absolventek ošetřovatelské školy, vydatná pomoc však přicházela také od žen-lékařek, které měly $k$ ošetřovatelkám vstřícnější vztah.

\section{Materiální a sociální podmínky v prvních poválečných letech}

Nebyly to však jen předsudky, co ztěžovalo zavedení moderních ošetřovatelských metod v Československu. Vážný problém zpočátku představovaly naprosto nevyhovující materiální a sociální podmínky pro studium a práci ošetřovatelek. Nemocnice, jejichž vybavení bylo vykradeno ustupujícími armádami na konci války, neposkytovaly ani nejnutnější zázemí pro odbornou práci a všeobecný nedostatek peněz znemož- 
ňoval okamžitou nápravu tohoto stavu. Výmluvné svědectví o těchto problémech podala Clara D. Noyesová, která na podzim 1920 podnikla inspekční cestu po Evropě. Ve své zprávě líčí extrémní podmínky, kdy na jedno celé oddělení Všeobecné nemocnice v Praze mohla být vydána jen jedna kostka mýdla sloužící pro potřeby lékařủ, ošetřovatelek i pacientů. Nedostatky byly ve vybavení nemocničních oddělení i v nevyhovující stravě, chybělo ložní prádlo, $\mathrm{k}$ dispozici bylo jen velmi málo kuchyní a sociálních zařízení, dodávky teplé vody byly pravidelně přerušovány (9). Při inspekci školy Noyesová upozorňovala na nevhodné pomůcky pro výuku ošetřovatelských předmětů, na špatnou skladbu a monotónnost jídelníčku (černý chléb bez másla a vařené brambory nebo párek) a na malé porce pro žákyně, které byly bledé a anemické a musely přitom podávat obrovský výkon. Na základě těchto zjištění bylo z Pařiže do Prahy posláno 18000 franků rozdělených mezi adeptky tak, aby nebyly závislé na nevyhovující nemocniční stravě a mohly si samy něco koupit a uvařit (7). Odstranění uvedených nedostatků však bylo na rozdíl od jiných problémů nemateriální povahy záležitostí poměrně krátkého období tří let.

\section{Hlavní úkoly Spolku absolventek ošetřovatelské školy}

$\mathrm{Za}$ změny se stavěl rovněž Spolek absolventek ošetřovatelské školy založený v roce 1921 a o sedm let později přejmenovaný na Spolek diplomovaných sester. Tato stavovská organizace inspirovaná americkým př́íladem se snažila vzbudit zájem o obor u mladých žen $s$ vyšším vzděláním, zasazovala se za důstojnější sociální podmínky sester $\mathrm{v}$ nemocnicích a dbala na udržení vysoké etické úrovně ošetřovatelské profese (19). Jeden z jejích velkých úkolů představovala otázka ř́zení ošetřovatelské péče a s ní spojená snaha zavést pozici civilní sestry představené. Tato inciativa reagovala na situaci po první světové válce, kdy nejpočetnější skupinou ošetřovatelského personálu $\mathrm{v}$ nemocnicích byly převážně nekvalifikované členky katolických řeholí a diakonky evangelické církve, zatímco české a německé diplomované sestry vykonávaly ošetřovatelskou péči jen ojediněle. Přitom vedoucí lékař mohl ř́dit jen civilní ošetřovatelský personál, řádové sestry vedla sestra představená, do jejíž pravomoci zasahovat nemohl. Proto také absolventky ošetřovatelských škol, které $\mathrm{v}$ nemocnicích zpravidla zastávaly funkci vrchní sestry, se u většiny ošetřovatelského personálu - řadových sester setkávaly s nepochopením. Absence řízení ošetřovatelské práce $\mathrm{v}$ nemocnicích před rokem 1920 se $\mathrm{v}$ praxi projevila tím, že mnoho úkolů, které náleží sestř̌e (měření pulsu a teploty, vpichování injekcí) vykonávali mladí lékaři. Prosazení pozice civilní sestry představené bylo za této situace naléhavým požadavkem (20).

\section{Doporučení americké strany}

V pohledu na ošetřovatelské školství se štěpilo nejen veřejné mínění v Československu, odlišné představy o jeho podobě měly i samotné americké organizace. ARC spolu s ČSČK na čele s Alicí Masarykovou se všeobecně přikláněly $\mathrm{k}$ vytváření široké sítě rychlého vzdělávání dobrovolných sester, jejichž služeb by bylo možné okamžitě využít $\mathrm{v}$ prrípadě epidemie či válečného konfliktu. Naproti tomu př́stup zastávaný představiteli RF byl promyšlenější strategií inspirovanou př́kladem amerických ošetřovatelských škol. Lze jej poměrně dobře vyčíst $\mathrm{z}$ první podrobné situační zprávy o stavu ošetřovatelství v Československu z roku 1922 (17), jejíz autorkou je Frances Elisabeth Crowellová, členka Mezinárodní zdravotní divize RF, zkušená ošetřovatelka a sociální pracovnice, která se zabývala zdokonalováním ošetřovatelského školství a ošetřovatelských standardů. V letech 1917-1923 sehrála důležitou roli při organizaci dispenzářů v boji $s$ tuberkulózou ve Francii a následně poté působila až do roku $1940 \mathrm{v}$ divizi RF pro studijní programy se sídlem v Pařízi.

Ve zprávě se konstatuje, že na stav ošetřovatelství má vliv řada politických a sociálních faktorů. Nová Československá republika jako multietnický státní útvar byla směsicí jazyků, národností a náboženství. Jiné byly podmínky v Čechách a jiné na Podkarpatské Rusi. Neexistoval jednotný nemocniční systém. Charitativní péče byla málo vyvinutá a soukromé kliniky fungovaly pouze pro platící pacienty. Začaly se sice stavět nové nemocnice, nicméně byl stále nedostatek li̊žek. Crowellová kritizovala zejména nedostatečné hygienické podmínky v československých nemocnicích. $\mathrm{V}$ žádném prípadě přitom nešlo o kritiku zaměřenou jen na Československo. Stejně př́sná byla i v hodnocení hygienických podmínek v Pittsburghu, kde po určitý čas působila. Uvědomovala si, že nedostatky v hygieně nejsou jen otázkou peněz, ale že je to $\mathrm{v}$ první řadě problém organizace. Zpráva dále upozorňuje na nevyhovující sociální podmínky laických ošetřovatelek, které se musely stravovat a bydlet př́mo na pokojích nemocných. Ve výhodě proti nim byly řádové sestry, jimž ubytování i soukromí zajištovala klášterní klauzura. Kritice autorka podrobila také naprosto nedostačující plat ošetřovatelek, který dosahoval sotva poloviční výše př́ijmu úřednic a učitelek, a vcelku trefně přirovnala postavení sester $\mathrm{k}$ pozici lepších služek, jejichž pánem byl lékař (17).

$\mathrm{Na}$ druhé straně Frances Crowellová dokázala ocenit, že i v tak obtížných podmínkách existovaly 
nemocnice $s$ čistými lůžky a komfortně zajištěnými pacienty, což platilo hlavně o dětských nemocnicích, v nichž působily jak řádové, tak laické sestry. Prvním krokem ke zlepšení profesionalizace oboru mělo být uzákonění a definice sestry profesionálky s vymezením kompetencí a požadavků na vzdělání. Navrhovaný ošetřovatelský odbor při ministerstvu zdravotnictví měl dohlížet na standardizaci vzdělávání na ošetřovatelských školách, kontrolovat zkoušky, evidovat registraci sester a vykonávat inspekci veřejných zdravotnických zařízení. Jako vzor vzdělávacího programu měl ministerstvu sloužit dvouletý program ošetřovatelské školy ve Štrasburku, jenž zahrnoval výcvik pro nemocniční i domácí péči. Crowellová naléhala také na spolupráci s německou sekcí ošetřovatelské školy při implementaci tohoto programu. Vzhledem $\mathrm{k}$ tomu, že pod vlivem Alice Masarykové měla sociální práce v Československu vyšší prestiž než ošetřovatelství, byl dvouletý program navrhován jako kombinace ošetřovatelství a sociální péče s možností specializace v druhém roce studia. Nejsilnější argument Crowellové pro kombinovaný typ vzdělávacího programu spočíval v nutnosti zavést výuku edukace pacientů. Uvedení těchto inovací do praxe však nebylo snadné, nebot naráželo na řadu byrokratických překážek. Problém byl v tom, že českou ošetřovatelskou školu řídil ČSČK, což byl soukromý subjekt, zatímco RF byla zaměřena na spolupráci $s$ veřejnými institucemi, zároveň však nesouhlasila s návrhem dostat ČSČK pod kontrolu ministerstva zdravotnictví (17).

Tato př́sná kritéria, jež se Frances Crowellová snažila v Evropě při své zdravotní inspekci uplatňovat, považovali někteří její američtí kolegové paradoxně za nedostatečná a obviňovali ji, že její program nedosahuje úrovně standardů amerického ošetřovatelského vzdělávání. Takové hodnocení však nereflektovalo evropskou realitu: to, co Američané vnímali jako nedostatečné, bylo často $\mathrm{z}$ evropského pohledu maximem možného. Zásluha Crowellové byla právě $\mathrm{v}$ tom, že díky svým zkušenostem dokázala zabránit mechanickému přenosu amerických standardů do poměrů jednotlivých evropských zemí (18).

Souběžně s inspekcí Frances Crowellové byla ve dnech 30. května - 1. června 1922 uspořádána v Praze konference ředitelů ošetřovatelských škol z Prahy, Poznaně a Varšavy, jíž předsedal Henry O. Eversole, ředitel evropské kanceláře RF. Toto jednání, na němž vystoupilo celkem 15 amerických ošetřovatelek, včetně Marion Parsonsové, Alotty Lentellové a Blanche Kacenové, představovalo jednu z prvních příležitostí $\mathrm{k}$ výměně názorů a zkušeností $\mathrm{z}$ dosavadního vývoje ošetřovatelského školství ve stř̌ední Evropě. Probrána byla celá řada aktuálních dílčích témat. Diskutovalo se nad tím, zda je možné vytvořit na školách v různých zemích Evropy standardní studijní plán, jak může Liga výuky ošetřovatelství pomoci s lepší připraveností absolventek na kurzy $\mathrm{v}$ zahraničí, jak překonat problémy s cizím jazykem, jaké př̀edměty mohou vyučovat ošetřovatelky AČK s pomocí tlumočníka, jaká práva by měla být poskytnuta řádovým sestrám, které na školách studují, a co by chtěla a mohla udělat vláda pro vytvoření pracovních míst a zvýšení platů (22).

Ještě před konferencí ředitelů, v týdnu od 18 . do 25. dubna 1922, proběhla $\mathrm{v}$ Praze také konference místních diplomovaných sester ARC, na níž si Marion Parsonsová, Pancy Besomová a Rachel Torranceová vyměnily poznatky a dosavadní zkušenosti s českými ošetřovatelkami, které se měly ujmout vedení školy po jejich plánovaném odchodu z Československa (22).

Ošetřovatelky ARC reorganizovaly v letech 19201923 obsahovou náplň studia na české ošetřovatelské škole a vybudovaly na různých československých klinikách sít vzorových školících stanic pro praktický výcvik dobrovolných ošetřovatelek Červeného křiže (23). Když Československo opouštěly, bylo již ošetřovatelské školství v poměrně konsolidovaném stavu, nicméně větší díl práce měly československé ošetřovatelky teprve před sebou. Záleželo však nyní už hlavně na nich samotných, nakolik a $\mathrm{v}$ jakém časovém horizontu se jim podaří uvést $\mathrm{v}$ život doporučení předložená na konferenci ředitelů ošetřovatelských škol a podrobněji rozvedená $\mathrm{v}$ situační zprávě Frances Crowellové. I když se nástupkyní Marion Parsonsové nakonec nestala Emilie Ruth Tobolářová vyškolená v Londýně, jak zástupci ARC původně předpokládali (8), nýbrž Sylva Macharová, absolventka vídeňské ošetřovatelské školy, měly americké prrístupy v ošetřovatelství agilního zastánce ve stále početnějším Spolku absolventek ošetřovatelské školy.

\section{VÝSTUPY}

Výzkum přispěl k současnému poznání problematiky ve třech oblastech:

1. Na základě zjištěných dat o profesní dráze amerických ošetřovatelek se podařilo na konkrétních příkladech doložit, že do Československa přicházely z USA vyškolené sestry, které většinou získaly praktické a organizační zkušenosti v ošetřovatelské službě za první světové války v Evropě. Ukázalo se, že velkým problémem byla jazyková bariéra, kterou se dařilo překonávat díky česko-americkému původu Blanche Kacenové, která tak mohla efektivněji realizovat praktickou výuku $\mathrm{v}$ nemocnici.

2. Hlavním problémem ve výuce, který se americké ošetřovatelky snažily od počátku řešit, byla změna poměru teorie a praxe ve prospěch praktických 
předmětů a zvýšení prestiže ošetřovatelské profese. Marion Parsonsová ve funkci ředitelky pražské ošetřovatelské školy včlenila již v roce 1920 do osnov nové kurzy o výživě invalidů, $\mathrm{z}$ bakteriologie, etiky a dějin ošetřovatelství. Nové osnovy připravila během svého pobytu v Praze v roce 1921 Mary McDowellová. Výuku zdravotní a domácí péče o děti vedenou odbornou školitelkou zcela nově prosazovala Pansy Besomová.

3. Doporučení amerických ošetřovatelek zahrnovala zř́izení speciálního ošetřovatelského odboru při ministerstvu zdravotnictví, který měl legislativně upravit kompetence a postavení sester včetně požadavků na jejich vzdělání. Současně jeho úkolem měla být evidence registrovaných sester a inspekce veřejných zdravotnických zařízení. Mezi návrhy se rovněž objevuje důraz na rozširrení sítě státních ošetřovatelských škol a na prosazení výuky edukace pacientů.

Působení zahraničních ošetřovatelek ARC a expertů RF ve velmi obtížných podmínkách prvních poválečných let je možno označit za svého druhu fenomenální počin, jehož vliv nebyl dosud dostatečně doceněn. Nelze nevidět paralelu mezi tehdejšími snahami bojkotovat implementaci nových ošetřovatelských př́istupů a současnými tendencemi obhajování údajně historicky osvědčených systémů vzdělávání sester na středních školách.

Dosavadní výzkum byl limitován dostupností použitých zdrojů. Př́ští bádání by se proto mělo primárně orientovat na studium amerických archivních fondů, jež mohou do této problematiky vnést nová zpřesňující zjištění.

\section{REFERENČNÍ SEZNAM}

1. Kutnohorská J. Historie ošetřovatelství. Praha: Grada Publishing; 2010.

2. Irwin J. Beyond Versailles: Recovering the Voices of Nurses in Post-World War I U.S.- European relations. Nursing History Review 2016;24(1):12-40.

3. Noyes CD. Department of Red Cross Nursing: Our Foreign Programme. The American Journal Nursing [Internet]. 1921 [cited $2016 \mathrm{Feb}$ 6];22(1):32-6. Available from: http://www.jstor.org/stable/3407898

4. Noyes CD. The Red Cross: The Prague Training School. The American Journal of Nursing [Internet]. 1919 [cited 2016 Feb 06];20(2):136-7. Available from: http://www.jstor.org/stable/3405597

5. Page B. The Rockefeller Foundation and Central Europe: A Reconsideration. Minerva 2002 [cited
2016 Feb 6];40:265-87. Available from: http://www. jstor.org/stable/41821213

6. Archiv hlavního města Prahy, fond Spolek diplomovaných sester, karton 69.

7. Dock LL., Pickett, SE., Noyes CD., Clement FF., Fox EG., Meter AR. Participation in international nursing education. In: History of American Red Cross Nursing. New York: The Macmillan Company; 1922. p. 1150-3.

8. Noyes CD. Deparment of Red Cross Nursing: Prague School. The American Journal of Nursing [Internet]. 1923 [cited 2016 Feb 6];23(8):676-80. Available from: http://www.jstor.org/stable/3406838

9. Noyes CD. Deparment of Red Cross Nursing: The Schools of Nursing in the Old World, Prague. The American Journal of Nursing [Internet]. 1922 [cited 2016 Feb 6];22(6):445-8. Available from: http:// www.jstor.org/stable/3407724

10. Irwin J. Nurses without borders: The history of nursing as U. S. international history. Nursing Historical Review 2011 [cited 2016 Feb 6];19(1):78-102. Available from: http://dx.doi.org/10.1891/1062-8061.19.78

11. Masarykův ústav a Archiv AV ČR, fond Korespondence Alice Masarykové, karton 4.

12. Čapek D. Ošetřování nemocných. Zdravotní příloha. Zprávy ČSČK 1922;2(1):33.

13. Kafková V.Zhistorie ošetřovatelství. Sestra 1991;1(2):9.

14. Parsons GM. Státní ošetřovatelská škola v Praze. Zprávy ČSČK 1921;1:141-4.

15. Noyes CD. Deparment of Red Cross Nursing: The Prague School of Nursing. The American Journal of Nursing [Internet]. 1920 [cited 2016 Feb 6];20(8):643-7. Available from: http://www. jstor.org/stable/3407377

16. Doering L. Power and knowledge in nursing; a feminist poststructuralist view. Advances in Nursing Science. 1992;14(4):24-33.

17. Vickers E. Frances Elisabeth Crowell. An Evaluation of a European Nursing Experience. [dissertation] [Internet]. The University of West Florida 1996 [cited 2016 Feb 6], p. 81-2. Available from: http://etd.fcla.edu/WF/WFE0000064/Vickers_ Elizabeth_Dwyer_199612_MA.pdf

18. Vickers E. Frances Elisabeth Crowell and the politics of nursing in Czechoslovakia after the first world war. Nursing History Review 1999;7:67-96.

19. Archiv hlavního města Prahy, fond Spolek diplomovaných sester, karton 69: stanovy spolku.

20. Kafková V. Z historie ošetřovatelství. Brno: Institut pro další vzdělávání pracovníků ve zdravotnictví, 1992. 
21. Americká ošetřovatelka o našich poměrech. Zprávy ČSČK 1923;3(1):14-6.

22. Noyes CD. Deparment of Red Cross Nursing: Conference of Training School Directors in Prague. The American Journal of Nursing [Internet]. 1922 [cited 2016 Feb 6];22(11):917. Available from: http:// www.jstor.org/stable/3406768

23. Lovčí R. Alice Garrigue Masaryková. Život ve stínu slavného otce. Praha: Togga, 2008.
KONTAKT NA HLAVNÍHO AUTORA

Mgr. Růžena Zaoralová

Ústav ošetřovatelství

Fakulta zdravotnických věd

Univerzita Palackého v Olomouci

Hněvotínská 3

CZ-775 15 OLOMOUC

Ruzena.Zaoralova@seznam.cz 